\title{
PEMBINAAN KADER KB DALAM MENINGKATKAN PENGGUNAAN METODE KONTRASEPSI JANGKA PANJANG (MKJP) PADA WUS DI DESA KARANGREJO KECAMATAN BLIMBINGSARI BANYUWANGI
}

\author{
Indah Kurniawati'), Wahyu Fuji Hariani'1), Putri Ely Wijaya1) \\ 1)Prodi D3 kebidanan, STIKes Banyuwangi, Jawa Timur, Indonesia \\ Corresponding author : Indah Kurniawati \\ E-mail : indahqurnia20@gmail.com
}

\section{Diterima 27 Juli 2021, Direvisi 04 Agustus 2021, Disetujui 05 Agustus 2021}

\begin{abstract}
ABSTRAK
Metode kontrasepsi jangka Panjang merupakan bagian dari program keluarga berencana sebagai uoaya mengatur kehamilan dan jarak usia ideal melahirkan. Kader memiliki peranan dalam mensukseskan program KB, untuk perlu dilakukan pembinaan kader. Permasalahan meliputi: 1). Masih rendahnya penggunaan metode kontrasepsi jangka Panjang. 2). Masih kurangnya pengetahuan kader KB tentang kontrasepsi jangka Panjang. 3). Kurangnya informasi kepada WUS (Wanita Usia Subur) tentang kontrasepsi jangka Panjang keuntungan,efektifitas, dan efek samping. Solusi yang ditawarkan meliputi: 1). Sosialisasi dan penyuluhan tentang program metode kontrasepsi jangka Panjang. 2). Pendampingan konseling kepada WUS untuk meningkatkan motivasi minat penggunaan MKJP. Sasaran dalam kegiatan pengabdian masyarakat ini adalah semua kader KB sebanyak 29 responden di wilayah Desa karangrejo kecamatan Blimbingsari kabupaten Banyuwangi. Kegiatan pengabdian ini menggunakan Teknik penyuluhan tentang kontrasepsi jangka Panjang melalui Teknik pre tes dan post tes penyuluhan, diskusi, dan pendampingan kader dalam pemberian konseling KB kepada WUS. Proses kegiatan pengabmas ini sebelum dilakukan penyuluhan kader diberiakn pre tes dengan tujuan untuk mengetahuai sejauh mana pengetahuan kader tentang MKJP, dan hasilnya banyak kader yang masih memilki pengetahuan yang kurang lebih $67,2 \%$ dari 29 kader, selanjutanya diberikan penyuluhan tentang MKJP mulai dari.macam-macam kontrasepsi jangka Panjang, keuntungan dan efeksamping, cara memberikan konseling kepada WUS. Hasil dari penyuluhan itu pengetahuan kader menjadi baik sebanyak 86,2\% dari 29 kader, dan diterapkan dengan memberikan konseling KB kepada WUS dengan baik, dilihat dari laporan banyakanya WUS yang berganti kontrasepsi MKJP.
\end{abstract}

Kata kunci: kader; kontrasepsi; MKJP

\begin{abstract}
Long-term contraception method is a part of the family planning programs as an effort to regulate pregnancy and the ideal age to give birth. Cadres have role in the success of the family planning program, so it is necessary to give guidance for them. The problems include: 1 ). the use of long-term contraception method is still low. 2). Lack of knowledge from family planning cadres about long-term contraception method. 3). Lack of information to Women of Childbearing Age about long-term contraception benefits, effectiveness, and side effects. The solutions offered include: 1). Socialization and counseling about long-term contraception method program. 2). Counseling guidance to Women of Childbearing Age to increase their motivation in using long-term contraception method. The target in this community service activity is all Family Planning cadres as many as 29 respondents in the area of Karangrejo Village, Blimbingsari District, Banyuwangi. This activity used counseling technique on long-term contraception through pre-test and post-test counseling techniques, discussions, and guidance to cadres in providing family planning counseling to Women of Childbearing Age. Before giving counseling to the cadres, the pre- test was given to know the extent of cadres' knowledge about long-term contraception method, and the result showed that many cadres still had low knowledge about it approximately $67.2 \%$ from 29 cadres. Then counseling was given about long-term contraception method starting from various types of longterm contraception, advantages, side effects, and how to provide counseling to Women of Childbearing Age. The results of the counseling and guidance showed that the cadres' knowledge was better as many as $86.2 \%$ from 29 cadres, and it was implemented by providing family planning counseling to Women of Childbearing Age well, it can be seen from the reports of the increase in number of Women of Childbearing Age who changed to long-term contraception method.
\end{abstract}

Key Words: cadres; contraception; long-term contraception method 


\section{PENDAHULUAN}

Program Keluarga Berencana sebagai upaya mengatur kehamilan, jarak dan usia ideal melahirkan. Mengatur kehamilan, melalui promosi, perlindungan dan bantuan sesuai hak reproduksi. Metode kontrasepsi yang dianjurkan adalah metode kontrasepsi jangka panjang karena dapat dipakai untuk jangka waktu yang lama, efektif, penghitungan biaya relatif murah dan juga aman.(BKKBN, 2016) Pemerintah Indonesia memperkirakan bahwa Penduduk Indonesia akan melonjak signifikan pada 2035 dari jumlah penduduk sebesar 305,6 juta jiwa. Indonesia akan menempati posisi kelima sebagai negara dengan jumlah terbesar di dunia. Pertumbuhan penduduk yang besar akan mengakibatkan bencana dalam demografi dibidang ketenaga kerjaan, kesehatan dan kesejahteraan penduduk.

MKJP (Metode Kontrasepsi Jangka Panjang) alat kontrasepsi yang digunakan untuk menunda kehamilan, serta menghentikan kesuburan yang digunakan dengan jangka panjang meliputi alat kontrasepsi dalam rahim IUD, Implan dan kontrasepsi mantap MOW dan MOP. Pemerintah melalui lembaga Badan koordinasi Keluarga Berencana Nasional (BKKBN) tengah menjalankan program Metode Kontraseptif Efektif. Rata - rata penggunaan di Indonesia masih tergolong rendah.(BKKBN, 2013)

Upaya mensukseskan kembali program KB khususnya metode kontrasepsi jangka Panjang pemerintah menyelenggarakan dengan program BPJS yang memberikan layanan kontrasepsi gratis bagi seluruh rakyat indonesia. Variasi pemberian layanan BPJS sengaja ditekankan pada layanan MKJP guna meningkatkan minat gratis dan cakupan MKJP yang sangat kecil dan menurun. Minat ibu untuk mengikuti KB tersebut harus di dukung juga dengan peran kader masyarakat guna meningkatkan pengetahuan dan memberikan pengaruh pada ibu.(Notoatmodjo, 2007)

Kader bertanggung jawab terhadap masyarakat setempat dan pimpinan yang telah ditunjuk oleh pusat pelayanan kesehatan, diharapkan dengan adanya kerjasama dengan tim kesehatan mereka dapat melaksanakan tugasnya sesuai dengan petunjuk yang diberikan (Koba et al., 2019). Menentukan tugas kegiatan kader, mengingat bahwa kader bukanlah tenaga profesional melainkan hanya membantu tenaga kesehatan melaksanakan pelayanan kesehatan. Kader merupakan ujung tombak dalam usaha pemerintah untuk mengurangi angka kelahiran. Kader juga bekerja secara sukarela guna meningkatkan jumlah aseptor KB di dusun atau daerah tempat tinggalnya. Pengetahuan kader tidak di dapatkan dengan sembarangan sebagai kader $\mathrm{KB}$, diperlukan mengikuti pelatihan dan bimbingan yang dilakukan oleh penyuluh lapangan keluarga berencana (PLKB), bidan dan petugas pelayanan kesehatan lainnya, kader dilatih dan mendapatkan pengetahuan mengenai alat/metode kontrasepsi, manfaat serta kekurangannya melalui pelatihan pelatihan yang ada.(Uno, 2016)

Program keluarga berencana kader memiliki peranan dalam memberikan motivasi kepada wanita usia subur. Tindakan memotivasi akan lebih dapat berhasil apabila tujuannya jelas dan didasari oleh yang dimotivasi. Oleh karena itu, setiap orang yang akan memberikan motivasi pada seseorang harus mengenal dan memahami benar-benar latar belakang kehidupan, kebutuhan serta kepribadian orang yang akan dimotivasi.(Wahyuningsih \& Fatmawati, 2019)

Berdasarkan data yang diperoleh dari kabupaten banyuwangi pengguna KB IUD sebesar 20.389 jiwa, pengguna MOW 7.236 jiwa, Pengguna MOP 579 jia, Pengguna kondom 3.659 jiwa, pengguna Impant 24.445 jia,pengguna suntik 108.732 jiwa, dan pengguna pil 50.575 jiwa. Pada Tahun 2017 kecamatan Blimbingsari terdapat $92 \%$ menggunakan MKJP, dan pada tahun 2018 pada bulan juni mengalami penurunan dalam penggunaan metode MKJP yaitu $37 \%$, dilihat dari data masih rendahnya pengguna kontrasepsi jangka Panjang di Desa Karangrejo. Program keluarga berencana merupakan hal yang sudah cukup dikenal oleh masyarakat luas, termasuk masyarakat desa. Hal ini tidak lepas dari peran bidan serta kader sebagai ujung tombak dalam upaya penyebaran informasi mengenai program keluarga berencana.(Yulifah \& Yuswanto, 2009). Usaha kader untuk menyukseskan program $\mathrm{KB}$ ini tergantung dari kemampuan dan keragaman kader itu sendiri, adapun pembedaan kemampuan dan keragaman kader antara lain karakteristik individu kader itu sendiri. Keberhasilan program KB yang dirasakan oleh WUS merupakan cermin kepedulian dan kesadaran dalam diri kader untuk membantu bidan, juga membantu WUS yang ingin ikut ber $-\mathrm{KB}$.

\section{METODE}

Pelaksanaan pengabdian masyarakat ini merupakan bagian dari kelanjutan hasil penelitian kami dengan judul Gambaran Pengetahuan Kader KB tentang kontrasepsi Jangka Panjang dalam peningkatkan minat WUS tahun 2019. Metode pelaksanaan melalui 
beberapa tahapan:1) survey lokasi dan perijinan,2) Pendataan kader KB di wilayah Desa karangrejo kecamatan Blimbingsari Banyuwangi, 3) sosialisasi dan penyuluhan kepada kader tentang MKJP (Metode kontrasepsi jangka panjang), 4) evaluasi.

1) Survey lokasi dan perijinan

Awal pelaksanaan kegiatan dengan melakukan survey lokasi di wilayah Desa karangrejo dengan mendata semua kader KB. Kemudian melakukan perijinan kepada pihak yang berwenang diantaranya perangkat desa dan bekerjasama dengan Bidan wilayah Desa Karangrejo. Sasaran pengabdian adalah kader $\mathrm{KB}$.

2) Pendataan kader KB wilayah

Bekerjasama dengan bidan wilayah untuk mendata semua kader KB di wilayah terdapat 6 dusun masing2 ada 4-5 kader terbagi dalam RT/RW dengan jumlah semua kader sebanyak 29.

3) Sosialisasi dan penyuluhan kepada kader tentang MKJP

Edukasi atau sosialisasi diberikan dengan menyampaikan tentang program keluarga berencana serta penyuluhan tentang MKJP yang sebelumya diberikan kuesioner untuk menggali sejauh mana pengetahuan kader mengenai macam-macam kontrasepsi jangka panjang, efektifitas, cara kerja kontrasepsi, keuntungan, dan efek samping.

4) Evaluasi dan laporan kegiatan

Evaluasi kegiatan pengabmas sebagai bentuk laporan pertanggungjawaban kegiatan dengan mengevaluasi hasil penyuluhan kader tentang MKJP.

\section{HASIL DAN PEMBAHASAN}

Pelaksanaan pengabmas ini sasaran adalah kader KB sebanyak 29 kader pelaksanaan dilaksanakan di badai desa karangrejo yang sebelumnya koordinasi dengan perangkat desa dan bidan wilayah dalam mengumpulkan kader KB wilayah. Pelaksanaan pengabdian ini pada tanggal 3 Mei 2019 bersama dengan mahsiswa tehnik pelaksanaan penyuluhan dengan Teknik pre tes dan post tes penyuluhan, ceramah, diskusi, tanya jawab dan pendampingan kader dalam pemberian konseling KB kepada WUS.

Kader di beri pemahaman tentang MKJP (Metode Kontrasepsi Jangka Panjang) meliputi: macam-macam kontrasepsi,cara kerja kontrasepsi, keuntungan, efektifitas dan efek samping pelaksanaan kegiatan tersebut kader sangat memperhatikan dan akan melaksanakan peranannya sebagai kader KB untuk meningkatkan cakupan MKJP.

Awal pelaksanaan sebelum penyuluhan kader dilakukan pre tes untuk mengetahui sejauh mana pengetahuan kader tentang MKJP dan di ketahui pengetahuan yang kurang lebih 62,7\% dari 29 kader. Dari hasil pre tes diketahui masih banyaknya kader yang belum tahu tentang program kontrasepsi jangka Panjang. Kemudian kader diberikan sosialisai dan penyuluhan untuk memberikan pemahaman te tang kontrasepsi jangka Panjang mulai dari keuntungan, cara kerja dan efektifitas dan bagaimana pemberian konseling yang baik kepada WUS.

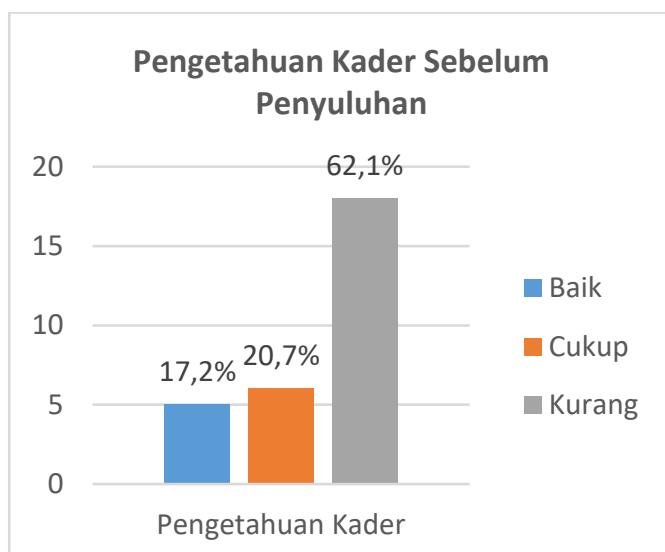

Gambar 1. Pengetahuan kader sebelum penyuluhan

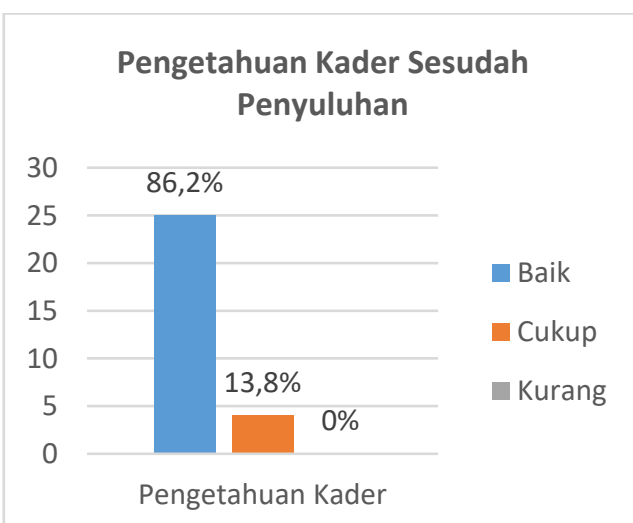

Gambar 2. Pengetahuan kader sesudah penyuluhan

Berdasarakan data di atas Setelah dilakukan penyuluhan melakukan evaluasi dengan pengisian kuesioner post tes dan hasilnya didapatkan hasil pengetahuan kader menjadi baik mencapai 86,2\%. Kegiatan penyuluhan ini mampu meningkatkan pengetahuan kader, yang kemudian sebagai kemampuan kader dalam memberikan konseling KB MKJP untuk meningkatkan minat berKB kepada WUS, sehingga cakupan MKJP di wilayah Desa Karangrejo meningkat. 


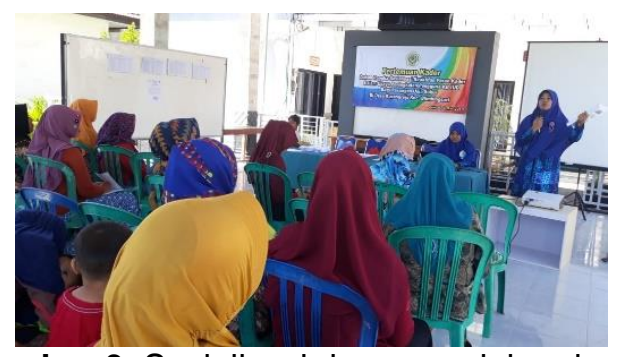

Gambar 3. Sosialisasi dan penyuluhan kader

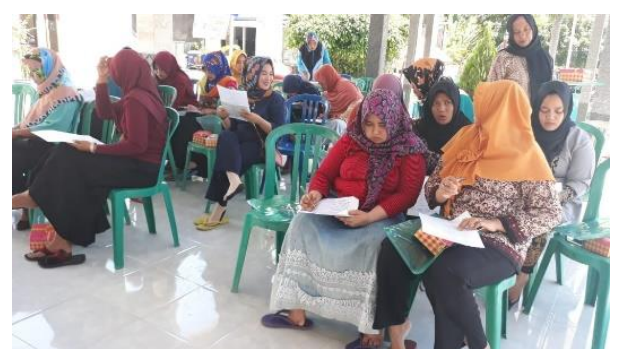

Gambar 4. Evaluasi hasil penyuluhan kader

\section{SIMPULAN DAN SARAN}

Setelah dilakukan kegiatan pengabmas ini dengan memberikan penyuluhan kepada kader KB dan sebagian besar sudah mempunyai pengetahuan yang baik tentang MKJP sehingga nantinya kader akan mampu memberikan konseling KB MKJP kepada WUS secara baik dan memberikan motivasi untuk meningkatkan minat penggunaan kontrasepsi jangka Panjang sehingga program keluarga berencana terlaksana dengan baik kesejahteran keluarga meninggakat dan kedepannya dapat menjadi referensi untuk kegiatan-kegiatan pengabmas selanjutnya.

\section{UCAPAN TERIMAKASIH}

Ucapan terimakasih kami sampaikan kepada PPPM Stikes Banyuwangi telah mendukung secara penuh terlaksanakan kegiatan ini dan mendanai pengabmas ini. Terimakasih kepada para perangkat Desa Karangrejo dan Bidan wilayah serta kader yang terlibat dalam penyelenggaraan kegiatan ini.

\section{DAFTAR RUJUKAN}

BKKBN. (2013). Laporan Akuntabilitas Kinerja Instansi Pemerintah.

BKKBN. (2016). Kebijakan Program Kependudukan, Keluarga Berencana, dan Pembangunan Keluarga dalam Mendukung Keluarga Sehat.

Koba, M. T. E., Mado, F. G., \& Kenjam, Y. (2019). Hubungan Tingkat Pengetahuan Akseptor Keluarga Berencana dan Peran Tenaga Kesehatan dengan Minat Penggunaan Kontrasepsi Jangka Panjang (MKJP). Media Kesehatan Masyrakat Indonesia, 1(1), 1-7. https://doi.org/https://doi.org/10.35508/mk m.v1i1.1515
Notoatmodjo, S. (2007). Promosi Kesehatan dan ilmu Perilaku. Rineka Cipta.

Uno, H. (2016). Teori motivasi dan Pengukuran. Bumi Aksara.

Wahyuningsih, D., \& Fatmawati, F. (2019). Hubungan Antara Dukungan Kader Dengan Minat Penggunaan Alat Kontrasepsi lud Pada Pus Di Desa Sukorejo Kecamatan Gurah Kabupaten Kediri. Judika (Jurnal Nusantara Medika), 3(2),

13-23. https://ojs.unpkediri.ac.id/index.php/akper /article/view/13095

Yulifah, R., \& Yuswanto, tri johan agus. (2009). Asuhan Kebidanan Komunitas. salemba medika. 